\title{
PALEOCLIMATOLOGICAL AND GEOARCHAEOLOGICAL SIGNIFICANCE OF THE HOLOCENE LOESS - SOIL SUCCESSIONS OF THE TIEN SHAN FOOTHILLS OF UZBEKISTAN
}

\author{
Fabian Welc ${ }^{1}$, Khodjiakbar Toychiew ${ }^{2}$, Małgorzata Suska-Malawska ${ }^{3}$, Leszek Marks ${ }^{4}$, Monika Mętrak $^{5}$ \\ ${ }^{1}$ Institute of Archaeology, Cardinal Wyszyński University in Warsaw, Wóycickiego 1/3, bud. 23, \\ 01-938 Warsaw,Poland, e-mail:f.welc@uksw.edu.pl \\ 2 Faculty of Geology, National University of Uzbekistan, Tashkent, Uzbekistan, e-mail: stelmakhag@rambler.ru \\ ${ }^{3}$ Faculty of Biology, Biological and Chemical Research Centre, Warsaw University, Żwirki i Wigury 101, \\ 02-089 Warsaw, Poland, e-mail: malma@biol.uw.edu.pl \\ ${ }^{4}$ Faculty of Geology, Warsaw University, Żwirki i Wigury 93, 02-089 Warsaw, Poland, \\ e-mail:leszek.marks@uw.edu.pl \\ ${ }^{5}$ Faculty of Biology, Biological and Chemical Research Centre, Warsaw University, Żwirki i Wigury 101, \\ 02-089 Warsaw,Poland, e-mail: mmetrak@biol.uw.edu.pl
}

\begin{abstract}
Scenario of climate changes in the Late Pleistocene and Holocene in Central Asia is very fragmentary and inconsistent. Therefore, interaction between the development and decline of ancient cultures and the climate fluctuations are difficult to be traced. To resolve this problem, the key role can be played by multidisciplinary studies of unique Late Pleistocene and especially Holocene loess - soil succession of the Tien Shan foothills in Uzbekistan. This area yields unique successions of paleosols interbedded with loesses that are particularly useful for paleoclimate analysis. They are represented by continuous and uninterrupted sedimentary sequences with a highly varied record of magnetic susceptibility. As such, they contain a full sequence of short-term climatic oscillations of the Holocene in high resolution and therefore, in this case, they are exceptional on global scale. The correlation of Late Pleistocene and Holocene climate changes scenario with stages of development and collapse of the past human settlement in Central Asia seems at present one of the most promising research directions, in line with the substantial course of interdisciplinary research on the interaction between humans and the natural environment.
\end{abstract}

Key words: Holocene climate change, geoarchaeology, Uzbekistan, Central Asia, loess - soil succession.

Manuscript received 25 August 2015, accepted 12 February 2016

\section{INTRODUCTION}

Recent investigations have indicated considerably high dynamics of climate change during the Holocene (see e.g., Mayewski et al., 2004; Staubwasser, Weiss 2006) defined as Rapid Climatic Changes (RCC) or Bond events (Bond et al., 1997, Bond et al., 2001). They are represented by several cool episodes that took place every 1500 years. By some researches these oscillations are considered as the DansgaardOeschger subcycles (see table below), which are the rapid climate change events very well recognizable in the GISP2 core by warming episodes followed by relatively slower cooling (Johnsen et al., 1992, Dansgaard et al., 1993, Grootes, Stuiver 1997, Voelker 2002, Huber et al., 2006, Overpeck, Cole 2006, Pisias et al., 2010, Petersen et al., 2013).

These rapid climate changes (RCC) have resulted in significant environmental transformations and exerted a great impact on the development and decline of ancient civilizations. Although it seems obvious that past cultures were influenced by climate changes, this issue has only recently been initiated in profound multidisciplinary investigations (Weiss 2000, Weiss, Bradley 2001, Staubwasser, Weiss 2006, Welc, Marks 2014). For example, one of the most significant RCC event, which occurred at $4200 \mathrm{BP}$, correlated with Bond Event 3 (De Menocal et al., 2000, Gasse 2000), presumably influenced the mid- to low-latitudes of the northern hemisphere. During that time the early Bronze Age civilizations collapsed, which is indicated by complete depopulation not only in Central Asia, but also in the Levant area, by the termination of the Akkadian Kingdom in Mesopotamia, the Old Kingdom in Egypt, and the Harappa civilization in India (Possehl 1997, Weiss 1997, Weiss et al., 1993, Madella, Fuller 2006, Welc, Marks 2014). 


\begin{tabular}{|c|c|}
\hline Bond event no. & Dating ka BP \\
\hline 0 & $0.5 \mathrm{ka}$ \\
\hline 1 & $1.4 \mathrm{ka}$ \\
\hline 2 & $2.8 \mathrm{ka}$ \\
\hline 3 & $4.2 \mathrm{ka}$ \\
\hline 4 & $5.9 \mathrm{ka}$ \\
\hline 5 & $8.2 \mathrm{ka}$ \\
\hline 6 & $9.4 \mathrm{ka}$ \\
\hline 7 & $10.3 \mathrm{ka}$ \\
\hline 8 & $11.7 \mathrm{ka}=$ Younger Dryas \\
\hline
\end{tabular}

man impact, and their deposition was strongly connected with changes of the monsoon circulation (An 2000, An et al., 2001, Guo et al., 2002; Sun et al., 2006).

\section{PALEOCLIMATIC SIGNIFICANCE OF THE LATE PLEISTOCENE AND HOLOCENE LOESS - SOIL SUCCESSIONS OF CENTRAL ASIA}

Generally speaking, loess deposition is driven mainly by climate and availability of source sediments. Climate is responsible firstly for weathering intensity, soil formation which in turn influences vegetation cover, deposition, erosion, diagenesis and reworking of deposits. Loess - soil successions can therefore be regarded as effects of changing environmental conditions, from soil formation (pedogenesis) to loess deposition, being strictly related to climate changes. In consequence, interbeddings of loess and paleosols were formed during different paleoenvironmental conditions, strictly related to climate (Derbyshire et al., 1995). During intervals with relatively warm and wet climate conditions, the deposition of the aeolian fine fraction did not occur or was very limited, while on topographic surfaces stabilized by vegetation, a more or less thick pedogenic cover developed, in which living organisms played an important role (bioturbations). Soils which developed during rapid and frequent environmental changes were truncated and buried, forming pedocomplexes with more than one paleosol (ancient soil) stacked on top of the previous one and resulting in the development of characteristic vertical successions. During dry and cool intervals, decrease or disappearance of vegetation cover favored physical weathering, erosion and transport of fine material that buried the previously formed soils. Therefore, the uppermost horizons of each paleosol are commonly eroded by deflation. However, the presence of subsurface and deeper horizons can provide, through paleopedologic investigations, unique data on climate conditions during their formation (Jary 2007).

Deposition of loess occurred with varying intensity and was discontinuous as indicated by rapid grain size changes or by paleosols (Jary 2007). The presence of coarse-grained loess was connected with dust storms, during which shortterm suspension and modified saltation predominated (Pye 1987). On the other hand, contribution of fine fraction indicates processes acting longer, during which transport in suspension prevailed (Sun et al., 2002). Paleosols evolved on past topographic surfaces and thus record environmental conditions in the vicinity, including climate, vegetation cover, biological activity, surface processes (geomorphology) and human activities. Therefore, often containing archeological remains, paleosols provide good proxy data for environmental conditions at the time of their formation.

Late Pleistocene and Holocene loess - soil successions in Central Asia locally attain thicknesses from several to a hundred meters (Kukla, An 1989, Rutter et al., 1991, Ding et al., 2002, Dodonov 2002; Dodonov, Zhou 2008). They are characterized by an almost complete lack of traces of cryogenic processes, therefore are often referred to as 'warm-climate loesses' (Smalley et al., 2001, Dodonov, Zhou 2008) (Fig. 1). It is assumed that aeolian deposition in the area in 
question started already approx. 7-8 Myr ago and was associated which was associated with the activation of the monsoon system (Guo et al., 2002). It has been already proven that these sediments are an excellent medium for stratigraphic and geochronological interregional correlation of the Late Quaternary climatic episodes (Murray, Wintle 2000, Roberts, Win- tle 2001, Zhou, Shack- leton 2001, Stevens et al., 2006, Lai et al., 2007, Dodonov, Zhou 2008), because their magnetic susceptibility reflects varying dynamics of pedogenic processes that were strictly connected with dynamics of climate chan- ges (Zhou et al., 1990, Heller et al., 1991, Maher, Thompson 1991, Forster, Heller 1994, Shackleton et al., 1995, An 2000).

\section{CENTRAL ASIA LOESS - SOIL SUCCESSION AND THEIR MAGNETIC SUSCEPTIBILITY PROPERTIES}

In recent times, magnetic susceptibility (MS) has been used as an important environmental proxy indicator in Quaternary science (Thompson, Oldfield 1986). The introduction of MS analysis has significantly helped to advance not only Quaternary stratigraphical research, but also to identify paleoenvironmental reconstruction in loess - soil succession (Kukla 1987, Zhou et al., 1990, An et al., 1991, Maher, Thompson 1991, Tang et al., 2003). Being an excellent climatic proxy, MS has been extensively applied in the recent years, however, the actual mechanism of susceptibility enhancement remains still debatable (Tang et al., 2003).

In general, magnetic susceptibility measures how different substances are magnetizable (Dearing 1994). This relationship is represented by the following formula:

$$
M={ }_{\chi} H
$$

where:

$M$ - magnetization of the material- measured in amperes per meter,

$\chi$ - voluminal magnetic susceptibility - dimensionless quantity,

$H$ - intensity of the magnetic field measured in amperes per meter.

Some minerals, such as magnetite and hematite, are strongly magnetic and they usually generate high magnetic susceptibility values. In the other side, quartz, calcium and organic matter are diamagnetic, it means that they usually generate extremely low magnetic susceptibility values. (Verosub, Roberts 1995).

Thompson, Oldfield (1986) measured the MS of various minerals and estimated without any doubt that specific content of ferromagnetic minerals is the leading factor controlling the MS intensity in sediments. In loess and paleosols the most important are such minerals as magnetite, titanomagnetite, maghemite, goethite, ilmenite, hematite, pyrite and pyrrhotite. Magnetic susceptibility measurements are commonly accompanied by measurements of isothermal remnant magnetization (IRM) and anhysteretic remnant magnetization (ARM) that indicate the varying concentration or grain size of ferromagnetic minerals.

Variable magnetic susceptibility of the Central Asian loess - soil successions is caused by alternate paleosols and loess beds in vertical succession. The most recent study show that soil magnetism is affected primarily by parent material and climate. Where parent material is constant, like the loess, the magnetism acts as a proxy for annual precipitation and to a lesser extent for annual temperature (Boyle et al., 2010).

It is widely accepted, that the paleosols present in loess succession were usually formed under relatively warm and humid climate conditions, during interglacial and interstadial periods. As a result, they produce relatively high magnetic value. For example, studies of the loess located in east southern Poland and western Ukraine shoved very great values of magnetic susceptibility (up to $600 \mathrm{x}$ SI units) in the horizons of non-gleyed interglacial paleosols (Nawrocki et al., 1996). On the contrary, the loess, characterized by low MS values, was deposited under cold and relatively dry, glacial conditions. Carbonates are also very important components of loess and paleosols. Their contents in loess formations are up to $20 \%$ (Tang et al., 2003). Paleosols rich in carbonate content, are usually also generating significant low value of the magnetic susceptibility. Paleomagnetic research of loess - paleosoil profiles in south-eastern Poland, clearly evidenced that the rise in carbonate content is followed by the decrease of the MS value (Issmer 2010). Maximum value of MS enhancement if all of the carbonates are leached out during pedogenesis is only $25 \%$. The MS value in paleosols is commonly 3-4 times higher that of loess in Chinese loess paleosol sequences (Tang et al., 2003).

It was also showed that at least part of magnetic signal generated by paleosols caused by abundant presence of magnetite or maghemite particles which are formed in situ by pedogenic processes (Evans, Heller 1994). Zhou et al., (1990) also attributed the magnetic enhancement in paleosols to some form of in situ process taking place during soil formation, all the above mentioned processes make the final interpretation of the MS measurements rather a complex task (Tang et al., 2003).

Maher, Thompson (1995) have measured modern soil magnetism in different climate zones across China (especially on Chinese Loess Plateau) and showed that there was a positive relationship between magnetic susceptibility and annual rainfall. They stated that, the lowest ferromagnetic concentrations occur under dry conditions with an annual precipitation of $300 \mathrm{~mm}$. The iron-oxide concentration gradually increases when annual precipitation reaches $750 \mathrm{~mm}$. Based on these observations, they argue that variations in rainfall on the Chinese Loess Plateau probably were at least four times larger than those inferred from current atmospheric circulation models.

Regardless of the controversies over usefulness of the magnetic susceptibility in paleoclimatic research, proxy records developed from loess - paleosol sequences of Central Asia are correlated with deep-sea cores and average oxygen isotope record for the past 7 kyrs (Forster, Heller 1994, Shackleton et al., 1995, Ding et al., 2002). They contain a very detailed record of abrupt climatic oscillations, because they are located in a transitional climatic zone between the northern extents of Indian monsoons and the North Atlantic circulation (Chen et al., 2009).

In recapitulation, we can state that, MS in recent times is widely used as excellent climatic proxy, contributing to the 


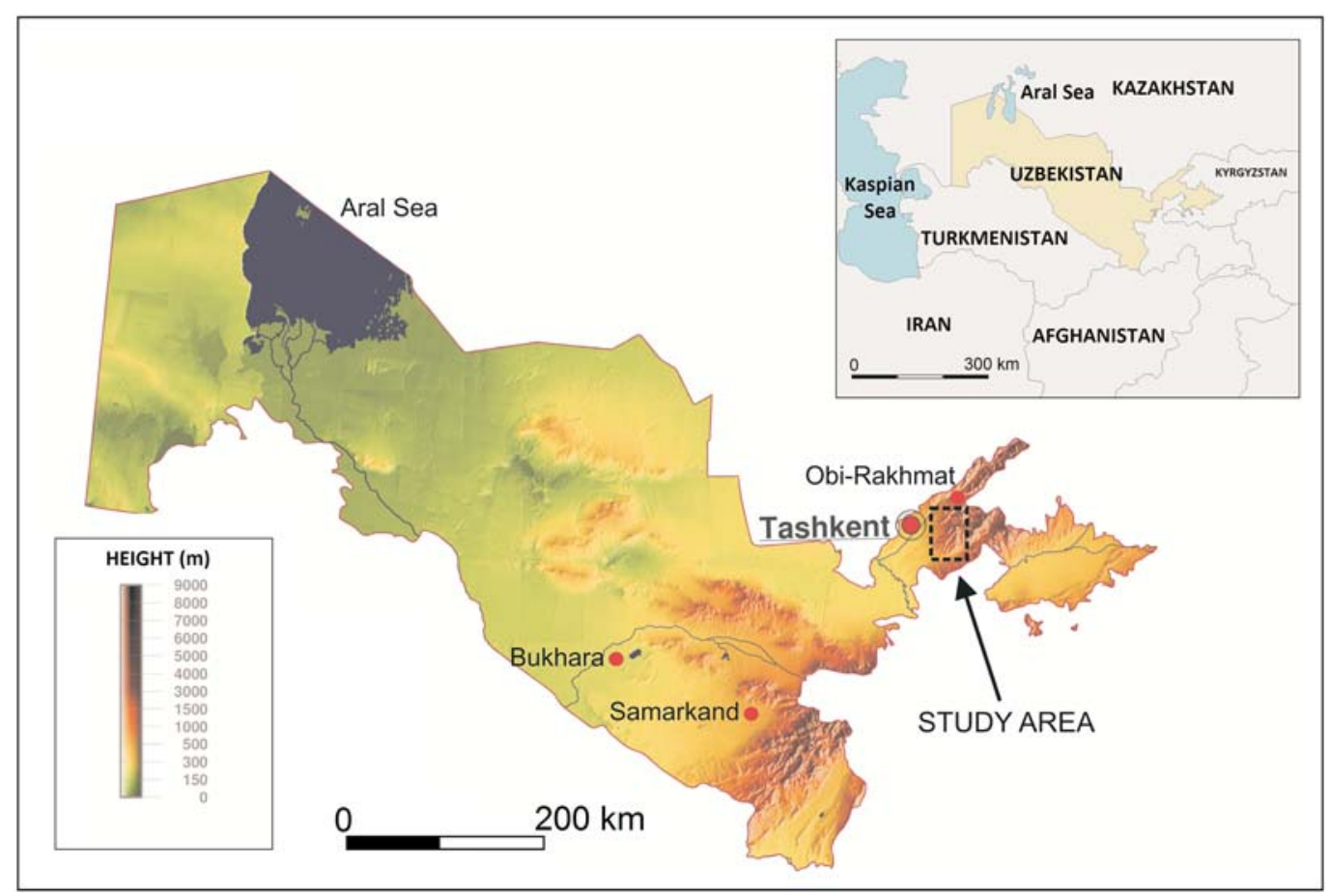

Fig. 2. Map of Uzbekistan showing localization of the study area (source: www.ginkgomaps.com).

reconstruction of past paleoclimate. However, there are still some controversies, such as physical reasons for MS enhancement, the role and origin of maghemite (Tang et al., 2003).

\section{HOLOCENE LOESS - SOIL SUCCESSION IN NORTHERN UZBEKISTAN}

In the Tien Shan foothills of northern Uzbekistan occurs a unique series of the Holocene polygenetic soils interbedded with loess sequences (Kovaleva 2004) that are particularly useful for paleoclimatic studies, including magnetic susceptibility analyses (Fig. 2). They are characterized by significantly high diverse MS values resulting from variable processes of their formation. The soils are represented by continuous and uninterrupted sedimentary sequences with a highly variable record of magnetic susceptibility. As such, they contain a full spectrum of short-term Holocene climatic oscillations in high resolution. Therefore, they are exceptional on the global scale.

Previous publications concerning Holocene and Late Pleistocene loess - soil successions in Central Asia provided only a simplified scenario of climate changes, based mainly on the analysis of ${ }^{13} \mathrm{C}$ and ${ }^{12} \mathrm{C}$ isotopes. The scenario begins with the Last Glacial Maximum (LGM) and enables to distinguish several key climatostratigraphic horizons (after Kovaleva 2004):

1. LGM (24,000-25,000 BP) with mean annual temperature well below $0^{\circ} \mathrm{C}$, followed by a cool and dry episode with mean annual temperature about $0^{\circ} \mathrm{C}$ and development of interstadial soils,

2. relatively wet interval at about $14,000 \mathrm{BP}$,

3 . cool and dry beginning of the Holocene $(11,700-$ $10,200 \mathrm{BP}$ ) with mean annual temperature about $0^{\circ} \mathrm{C}$,
4. wet and warm Holocene optimum (10,200-4,500 BP) with mean annual temperature considerably higher than at present, getting less warm and more dry at the termination of this interval,

5. 4,000-3,000 BP with climatic conditions similar to present ones, however at first more wet, after 3,000 BP more dry and with a gradually increasing human impact. This scenario is very simplified, which results from the lack of high-resolution paleoclimate data. The record of RCC events in loess soil sequences of the Tien Shan foothills may thus be of key importance for the reconstruction of the climate system on a pan regional scale.

From the view of future research projects, particularly significant are exposures of Late Pleistocene and especially Holocene loess - soil succession in Ingijul, Abaj, Karasu, Kadyrja, Apartak, and Arkutsaj (Fig. 3). For studies on Holocene climate changes, the most important are the Abaj and Karasu exposures in the central Chichiq River basin (Fig. 4). Preliminary analyses conducted by Prof. Khodjiak- bar Toychiew in these two exposures fully confirmed the high magnetic variability of the loess - soil covers. Preliminary MS examination of the Holocene loess - soil succession on the margin of the Karasu River valley (Fig. 5) undoubtedly indicated the presence of an extremely high-resolution record of long- to short-term climatic oscillations.

The exposure of Holocene loess - soil series in Karasu valley is located in the central part of the Chirchik river-basin, on the left bank of the Karasu River. At the present time, it is almost vertical wall, several metres high, created by erosive activity of the Karasu River. The exposure reveals almost horizontal sequence of the loess deposits, alternating with paleosoils horizons and alluvial silt and gravel sediments. So far, the Karasu profile was examined mostly as far 


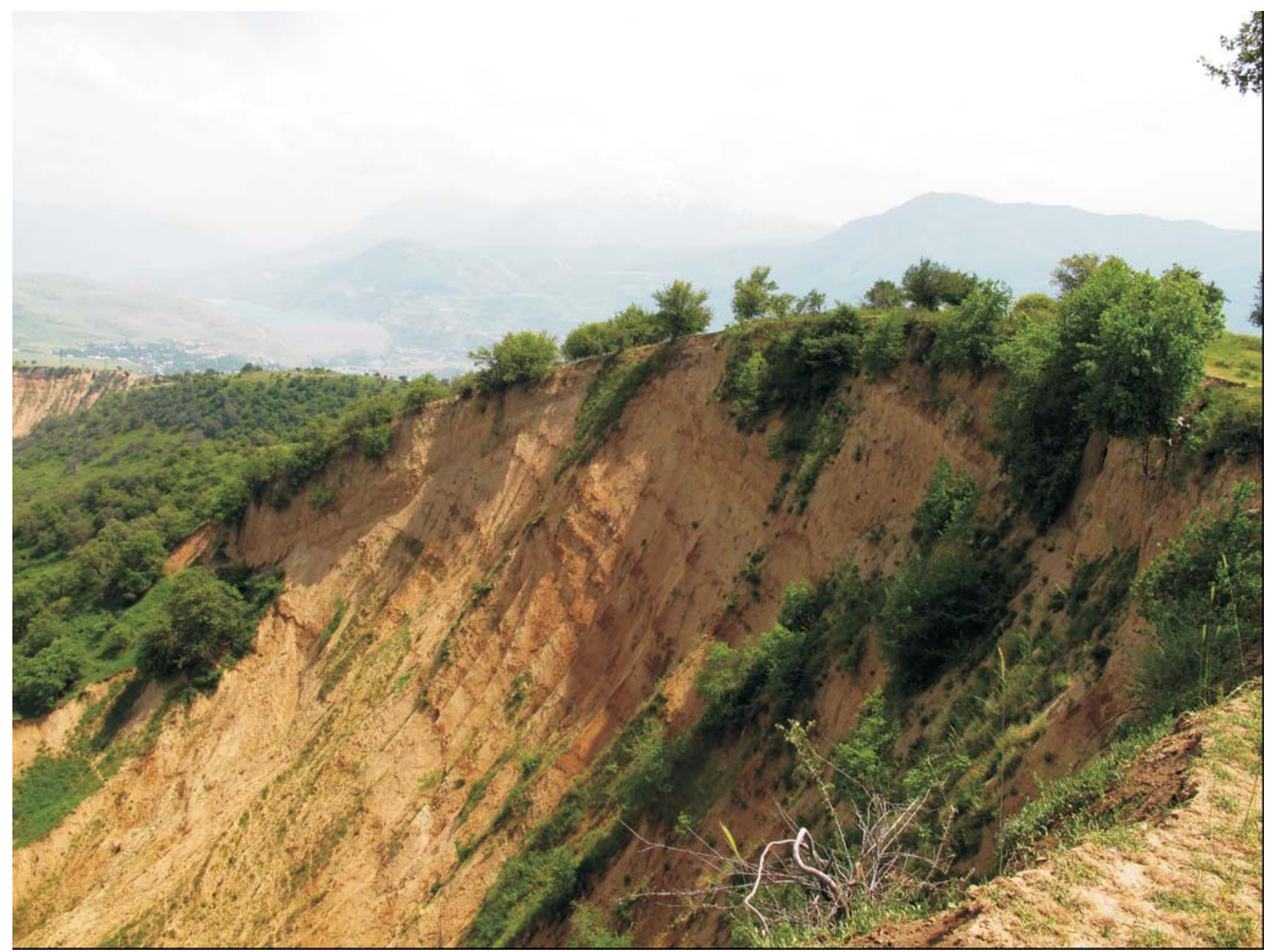

Fig. 3. Late Pleistocene and Holocene loess - soil exposure in Arkutsaj Valley, Tien Shan foothills in Uzbekistan. Fot. M. Suska- Malawska.

as paleomagnetism and MS are concerned. 24 oriented samples were taken from the exposure, and then they were intended to the paleomegnetic measurements.

Described exposure is about $5 \mathrm{~m}$ in height and revealed following lithological composition (going from the top to the bottom of the profile, Figs 4, 5):

1. modern soil (SG-1), grey colour, about $0.30 \mathrm{~m}$ in thickness,

2. the silty loess of dark grey colour with thickness of $2.40 \mathrm{~m}$,

3. upper paleosol horizon (PG-2), grey colour, about $0.25 \mathrm{~m}$ in thickness,

4. the silty loess of dark grey colour with thickness of $0.15 \mathrm{~m}$,

5. lower paleosol horizon (PG-3), grey colour, about $0.50 \mathrm{~m}$ in thickness,

6. the silty loess of dark grey colour with thickness of $0.15 \mathrm{~m}$,

7. layer of alluvial muds, the dark grey colour with interbeddings of gravels and pebbles, about $0.20 \mathrm{~m}$ in thickness,

8. layer of pebbles with diverse diameter.

The above described lithological sequence is characteristic for the second terrace of the Karasu River. Generally speaking, this series consist of three Holocene loess layers separated with two levels of paleosols (PG 2-3). The bottom part of the series is determined by alluvial sediments of different granulometric composition, i.e. muds and the lowest lying river gravels. Such lithological structure reflects several sedimentation episodes that took place during different environmental conditions. The loess layers were deposited during dry and windy periods, probably with occasional heavy rainfalls, while the soils were formed during stable and relatively moist intervals. Therefore, individual complexes of loess and soils reflect environmental changes in the region as a whole, thus making the Karasu profile a valuable archive of high resolution paleoclimatic data. According to prof. K. Toychiew, we can estimate the Holocene series in Karasu on approx. 13,000 years, on the basis of paleomagnetic scale. The lack of radiocarbon dates currently prevents any attempts to interpret the paleoclimatic aspects of the exposure, but there is no doubt that the profile reveals a very detailed scenario of climate fluctuations, especially those short-lived, as for instance - Bond cycles.

Although the issue will not be raised in more detail in this article, it must be noted here that, genesis of the loess - soil complexes in Chirchik river-basin, seem to be very complex. (Smalley et al., 2006). Yeliseyev (1973) described five theories which try to explain formation of loess deposits in Central Asia and especially in Uzbekistan: these were the prolu- 


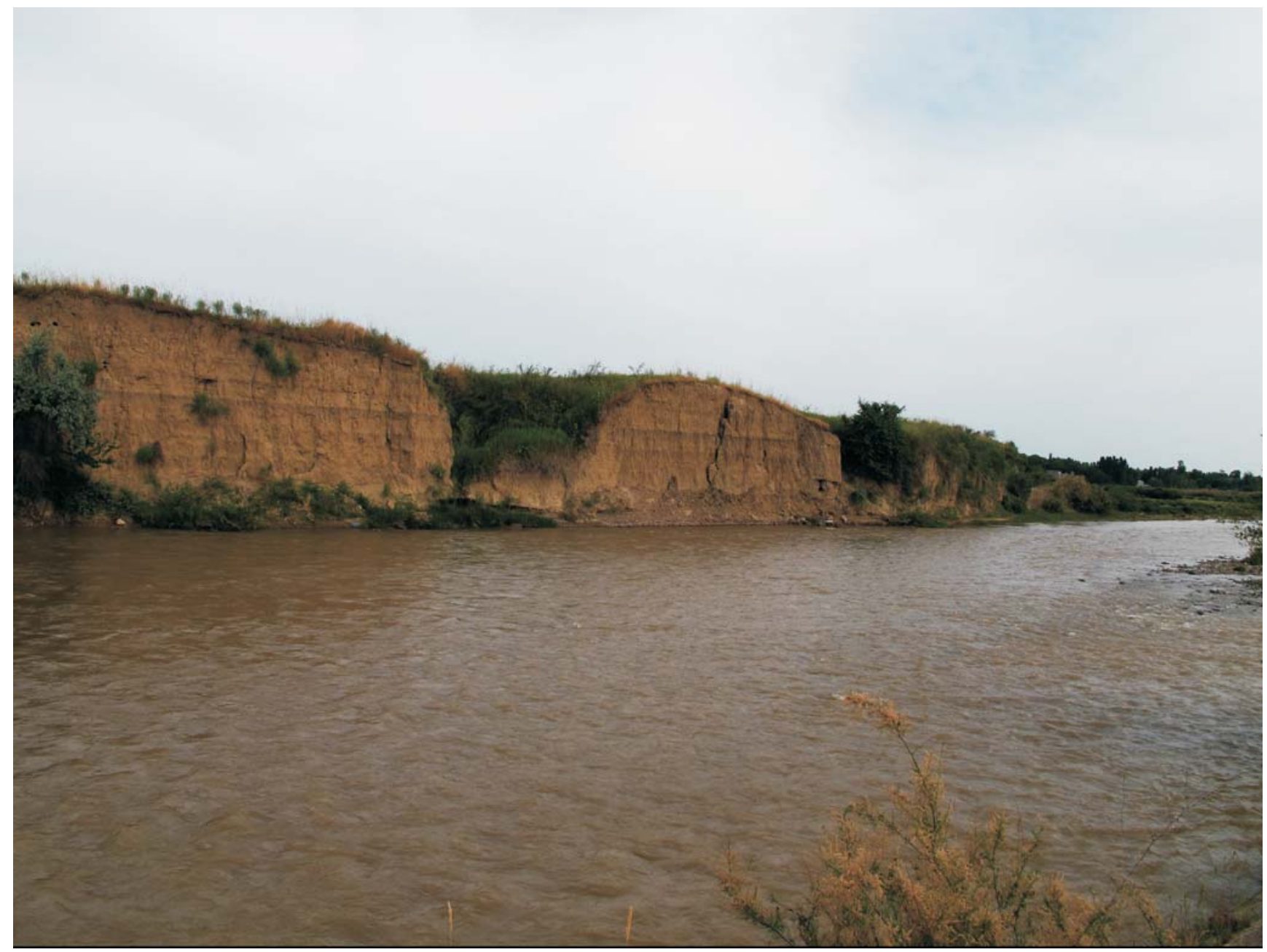

Fig. 4. Holocene loess - soil exposure on the Karasu river bank, Tien Shan foothills, Uzbekistan. Fot. M. Suska-Malawska.

vial (wadi like deposits), alluvial, the soil-eluvial, deluvial and the aeolian deposition concepts. All these terms can be summarized by the so called polygenic theory (Smalley et al., 2006). The large loess deposits in the vicinity of Tashkent, in the north-east of Uzbekistan (including Karasu valley deposits), seem to be formed according to polygenetic formation theory, which favours a proluvial mechanism (Fig. 6). The latter term was coined by Pavlov $(1888,1898)$ in the late nineteenth century. Generally speaking, the proluvial sediments were deposited by water on the plains. Mavlyanov et al., (1987) stated that "in Uzbekistan the following loess types were found: loess of proluvial genesis and loess-like rocks of proluvial, deluvial, alluvial, eluvial, uvio-glacial origin". However, it is still difficult to find a detailed description of the typical proluvial sedimentation. Dodonov (1991) used the word 'wadi' relative to proluvial deposits. Recent studies suggest also, that prololuvial sediments in the Chirchik river-basin could be topped with typical aeolian deposits (Smalley et al., 2006).

\section{GEOARCHAEOLOGICAL SIGNIFICANCE OF THE LOESS - SOIL SERIES IN UZBEKISTAN}

As it was mentioned above, the rapid climate fluctuations must have largely contributed to the fall of ancient civi- lizations and societies. The correlation of a precise scenario of Late Pleistocene and Holocene climate changes with the settlement and depopulation stages in Central Asia seems at present one of the most promising research directions, in line with the substantial course of interdisciplinary research on the interaction between humans and the natural environment.

In Central Asia there are numerous archaeological sites, with the most recent ones connected e.g. with the trans-Asiatic Silk Road. Artifacts from these sites, collected during many years of excavations, enabled to investigate both the cultural development of humans and their interaction with the natural environment ( $\mathrm{Li}$ 1992). For example, in Uzbekistan the oldest traces of past societies settlement have been discovered in the Sel 'Ungur cave (Ferghana region), dated at ca. 126,000 BP (Islamov et al., 1988). These findings are attributed to the lower Paleolithic flint industry (Vishnyatsky 1999). In turn, the most important Upper Paleolithic sites are the Obi-Rakhmat cave (cf., Fig. 2) and the exposure in Kul'Bulak, containing stratigraphic sequences encompassing the interval between 90,000 and 40,000 BP (Derevianko et al., 2004, Blackwell et al., 2006). It is worth noting that in Central Asia there are very few sites dated at the late Paleolithic. Ranov, Davis (1979) already suggested that this could have been caused by unfavorable environmental conditions that hampered human settlement. Despite the significance of 
climate changes for human history, the attempts to correlate them with the development of Middle and Late Paleolithic human cultures in Central Asia were undertaken rarely and usually with a single-sided approach. Therefore, the proposed models are usually inconsistent (Glantz et al., 2004). Nevertheless, one of the key questions in the spread and development of past cultures is the immigration of humans in the area at the end of the Last Glaciation (Glantz 2010). The record of climate changes in the loess - soil successions of the Tien Shan foothills in Uzbekistan may be of high importance in the recognition of the precise scenario of Late Pleistocene and Holocene climate changes, as well as for the attempts of their correlation with geoarchaeological data. Combination of these aspects will enable understanding of the interaction between Late Paleolithic human migration and settlement, and climate changes.

Furthermore, the onset of interglacial conditions at the beginning of the Holocene in Central Asia caused opening of new environments to human communities and is also related to a rapid climate change, although its mechanisms have been not yet fully explained. Such abrupt change is connected with the fluctuation of the North Atlantic Oscillation (Lamy et al., 2006), transformations of thermohaline circulation (Bond et al., 2001, cf. also Cubasch et al., 1997, Lamy et al., 2006) and advent of the Bond events (cooling intervals) (Staubwasser, Weiss 2006, Staubwasser et al., 2003). The basic issue that needs to be explained is the relationship between these megacycles and climate changes (Lamy et al., 2006).

It is commonly assumed that at the beginning of the Holocene in Central Asia a regionally variable climate prevailed with predominance of desert conditions (Zhao et al., 2008). Results of studies of sediments in the Bosten Hu Lake (southern margin of the Tien Shan Mts), conducted by Yang et al., (2008), suggest that the basin was almost completely devoid of water in the interval between the end of the Last Glaciation to the Early Holocene. It filled up again as late as ca. $8000 \mathrm{BP}$. Interestingly, different results were obtained during studies in the western part of the Chinese Loess Plateau (Zhao et al., 2008). They point to a relatively fast transformation of a desert steppe, characteristic for the Late Pleistocene, into a forest and a forest steppe during the Early Holocene, which can be directly connected with the domination of humid climate. Its final desertification took place as late as ca. 4,000 $\mathrm{BP}$, which is recorded in the area by the return of steppe vegetation (Zhao et al., 2008). Similar outcomes were obtained in the analysis of the Juyanze Lake deposits from north-western China. They point to the presence of a large fresh water basin in the early Holocene. About 8,000 BP, significant climate fluctuations resulted in famine, which is correlated with the onset of a cold and dry interval at ca. 7,500 BP. The next humid episode occurred between 5,400 and ca. 4,000 BP. Thereafter, the climate dried up leading to the complete disappearance of the lake. According to Hartmann, Wünnemann (2008), these phenomena can be linked with mutual interaction between the monsoon zone and the North Atlantic circulation.

An analogous scenario of the Early Holocene environmental transformations in Central Asia is presented by Baibatsha (2012). According to him, a warm and humid climate prevailed in the Early Boreal (BO-1, ca. 9,200-8,000 BC),

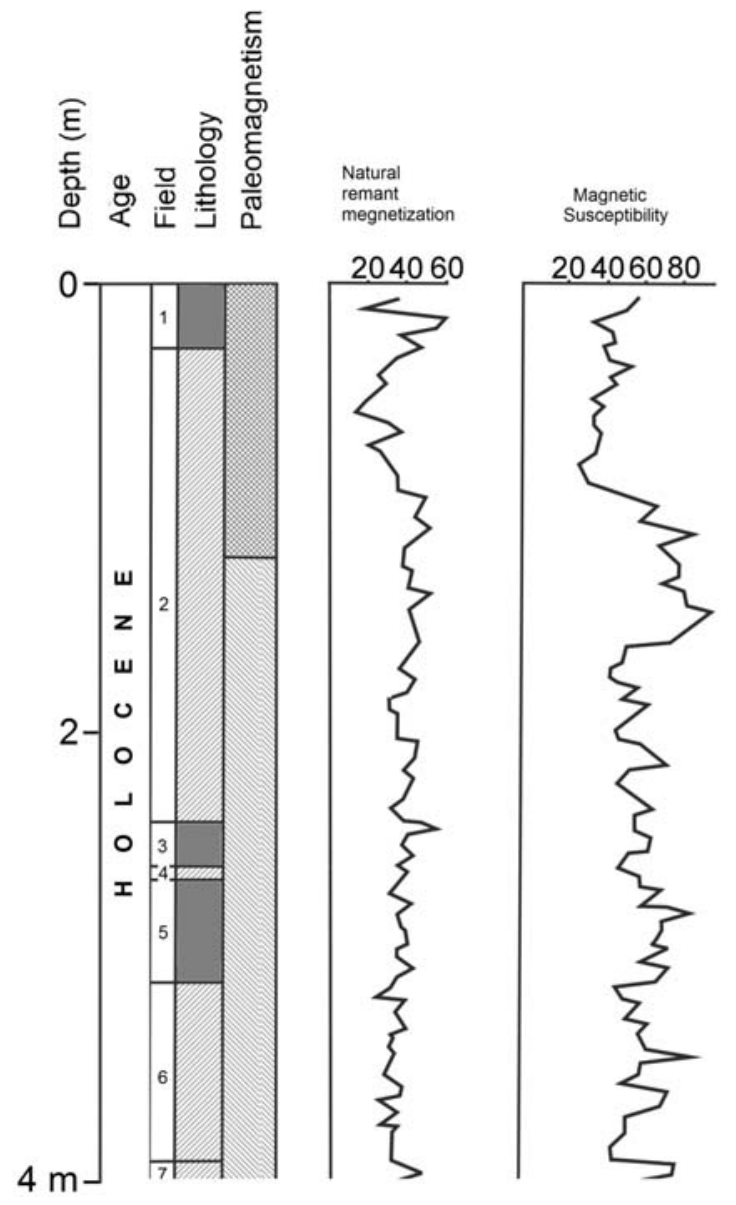

Fig. 5. Magnetic susceptibility and natural remnant magnetization recorded in Karasu loess - soil deposits. See description of the lithological units in the text. Drawing F. Welc, after Khodjiakbar Toychiew, unpublished materials.

which in Kazakhstan and Uzbekistan coincided with the beginning of the Neolithic. Due to rapid temperature increase within the Tien Shan belt, fast deglaciation of mountain glaciers took place, which probably caused catastrophic floods through excessive runoff of the Alatau meltwater into lowland areas. These phenomena almost completely stopped human settlement in entire Central Asia. In the middle of the Atlantic period (AT-2), that is ca. 7,000 BP, subsequent cooling and thus deterioration of climatic conditions took place, causing the extinction of large steppe animals. Humans, adapting to changeable conditions, began to domesticate horses and cattle.

This brief data analysis indicates that significant climate changes in Central Asia should be dated at the beginning of the $8^{\text {th }}$ millennium BP and may be linked with Bond Event no. 5. Bar-Matthews et al., (1997), Neff et al., (2001), Staubwasser et al., (2002), Fleitmann et al., (2003) mention that the existing data from the Middle East (e.g., Anatolia, Iraq, Iran), particularly the Levant region, unequivocally evidence that ca. 8,200 BP rapid climate fluctuations caused fast decline of human settlements and entire regions were depopulated, e.g. in northern Mesopotamia and Central Asia (Staubwasser, Weiss 2006). 


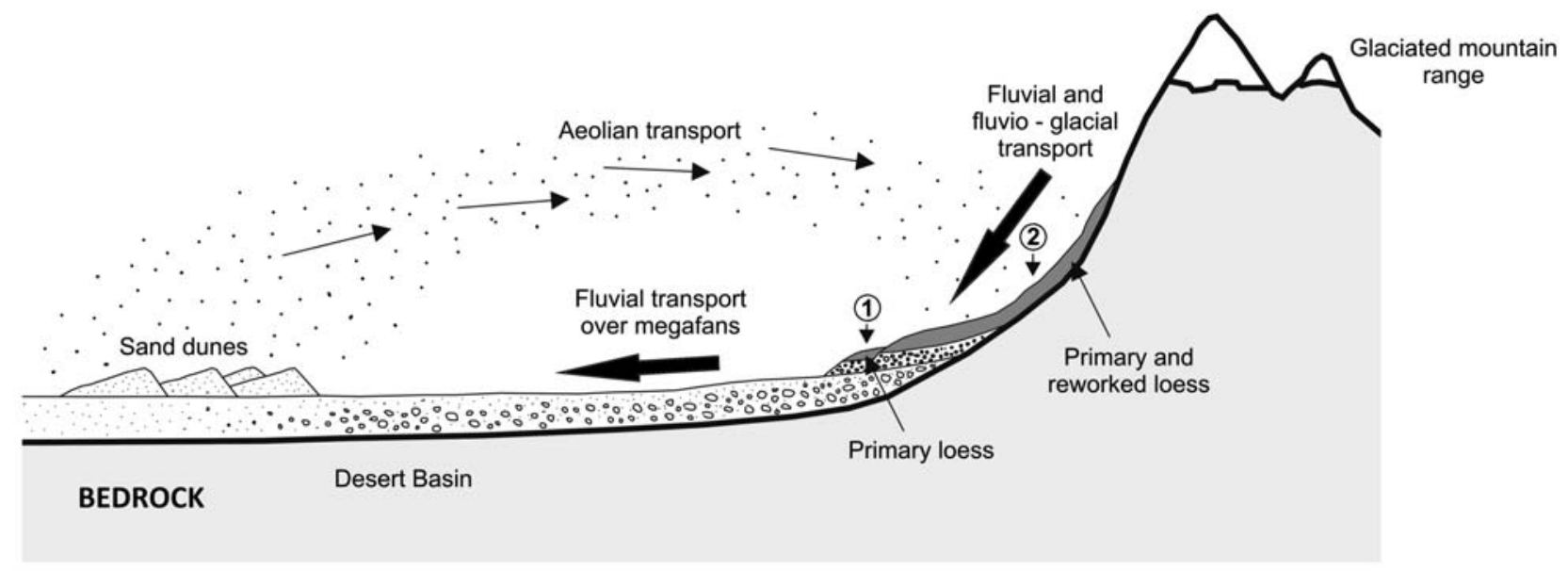

(1)



2

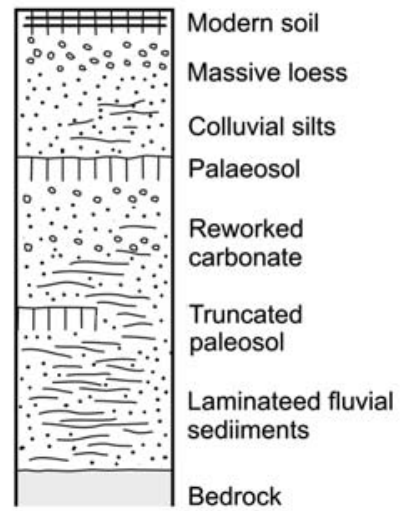

Fig. 6. Model of the loess deposition in Tien Shan foothills (Tashkent district) illustrated by Pye, Sherwin (1999), changed by F. Welc.

According to the present knowledge, the most favorable conditions for human settlement in Kazakhstan and Uzbekistan occurred in the Late Atlantic (AT-3), ca. 6,000-5,000 BP. Humid and warm climate promoted dense vegetation, which in turn stimulated development of cattle breeding (Baibatsha, 2012). Most probably with this interval can be linked the largest galleries of rock paintings presenting cattle from the Sarmish-Say valley in Uzbekistan (Rozwadowski 2001, 2004) (Fig. 7).

The next subsequent noticeable climatostratigraphic horizon in Central Asia was the interval dated between ca. 5,100 to 4,200 BP, when breeding of domesticated cattle declined, e.g. in the vast steppes of Kazakhstan. The culmination of this process took place at ca. 4,200/4,000 BP, which corresponds to the beginning of the great migration of Scythian tribes, the accompanying famine and the almost complete extinction of cattle population (Geel et al., 2004). It is commonly accepted that the area of the Central Asian steppes rapidly begins to dry up from this moment (Baibatsha, 2012). According to paleoclimatic data, ca. 4,200 BP (Bond Event No. 3) took place one of the most significant Holocene climate fluctuations on the global scale, which influenced the rapid collapse of large civilizations of the Bronze Age. So far, paleoclimatic analyses indicate that this anomaly had a duration of ca. 300 years. Most probably resulted from simultaneous weakening of the western circulation linked with the
NAO and disturbances of the monsoon system in Asia (Staubwasser, Weiss 2006, Staubwasser et al., 2003). At that time, an estimated reduction of precipitation by over ca. 30\% took place in Palestine (Bar-Matthews et al., 1997) and by almost $74 \%$ in the Tell Leilan area at the Turkish-Iraqi borderland (Staubwasser, Weiss 2006). At the same time deposition of silt deposits took place in Western Asia, which correlated with further decline of precipitation intensity. Climate fluctuations linked with Bond Event No. 3 were present both in Asia and Africa (Gasse 2000, Weiss, Bradley 2001, Booth et al., 2005, Staubwasser, Weiss 2006). Presently available data suggest that this phenomenon is not marked by the same signal in the paleoclimatic record. Contrastingly to the Middle East, in Morocco (Lamb et al., 1995), northern China (Hong et al., 2005, Wunnemann et al., 2006) and Central Asia (Ricketts et al., 2001), an opposite process took place, i.e. annual mean precipitation increased. An analogous phenomenon, although of a very short duration, was noted in northern Egypt (Welc, Marks 2013). According to Chen et al., (2009), this asynchroneity may result from an insufficient amount of available data, an imprecise chronostratigraphic framework or lack of assessing the human impact on the environment, i.e. anthropopression (Chen et al., 2009). 


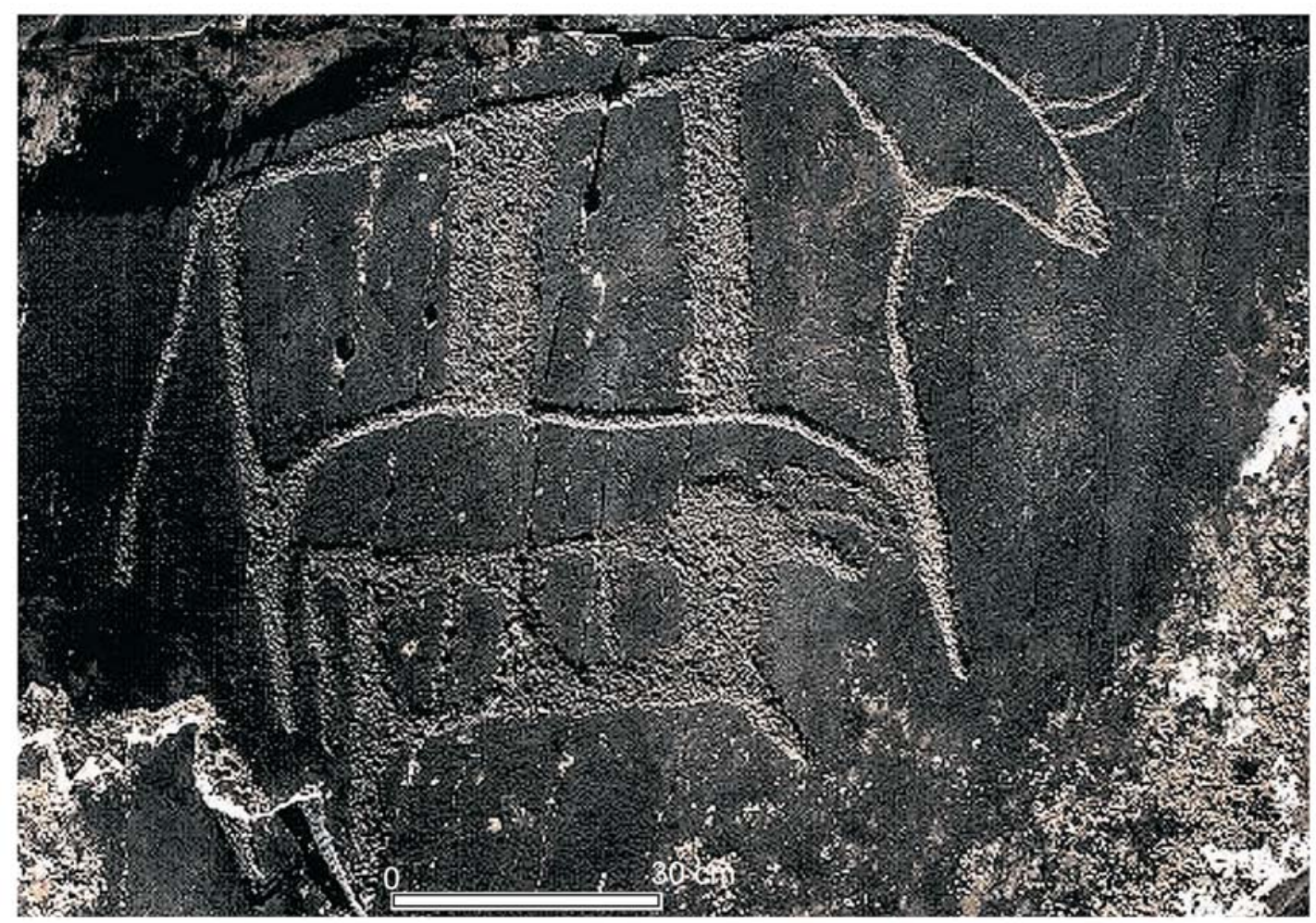

Fig. 7. Fragment of the rock impression in co called animal style. Sarmish-Sar Valley in Uzbekistan. Fot. Andrzej Rozwadowski (source: www.bradshawfoundation.com).

\section{CONCLUSIONS}

Summing up, the scenario of climate changes in the Late Pleistocene and Holocene in Central Asia is very fragmentary and inconsistent, therefore the real interaction between the development and decline of ancient cultures and the changes or short-term climate fluctuations, both in regional and pan regional scale are difficult to be traced. Thus, the key role can be played by multidisciplinary studies of unique Late Pleistocene and especially Holocene loess - soil succession of the Tien Shan foothills from Uzbekistan. This area yields successions of paleosols interbedded with loesses that are particularly useful for paleoclimate analysis (Kovaleva 2004). They are represented by continuous and uninterrupted sedimentary sequences with a highly varied record of magnetic susceptibility. As such, they contain a full sequence of short-term climatic oscillations of the Holocene in high resolution and therefore, in this case, they are exceptional on global scale.

The significance of the loess - soil exposures from Uzbe- kistan seems even more important, owing to the fact that the mechanism of the Bond cycles has not yet been fully explained. It is clear that rapid and catastrophic fluctuations occurred, that contributed to the decline of entire civilizations and societies. The correlation between a precise scenario of Late Pleistocene and Holocene climate changes with stages of settlement and depopulation in Central Asia seems at present one of the most promising research directions, in line with the substantial course of interdisciplinary research on the interaction between humans and the natural environment.

\section{REFERENCES}

An Z.S. 2000. The history and variability of the East Asian paleomonsoon climate. Quaternary Science Reviews 19, 171-187.

An Z.S., Kukla G.T., Porter S.C. 1991. Magnetic susceptibility evidence of monsoon variation on the loess plateau of central China during the last 130,000 years. Quaternary Research 36, 29-36.

An Z.S., Kutzbach J.E., Prell W.L., Porter S.C. 2001. Evolution of Asian monsoons and phased uplift of the Himalaya - Tibetan Plateau since late Miocene times. Nature 411, 62-66.

Baibatsha A.B. 2012. Anthropogenic history of Kazakhstan. Almaty 2012.

Bar-Matthews M., Ayalon A., Kaufman A. 1997. Late quaternary paleoclimate in the eastern Mediterranean region from stable isotope analysis of speleothems at Soreq Cave, Israel. Quaternary Research 47, 155-168.

Blackwell B., Mian A., Baboumian S., Blickstein J., Skinner A., Wrinn P., Krivoshapkin A., Derevi'anko A., Wagner J., Patchett P. 2006. Settling the age dispute for the Late Middle Paleolithic at the Obi-Rakhmat hominid site, Uzbekistan. Presentation at the Paleoanthropology Society Meetings in San Juan, Puerto Rico.

Bond G., Kromer B., Beer J., Muscheler R., Evans M.N., Showers W., Hoffmann S., Lotti-Bond R., Hajdas I., Bonani G. 2001. Persistent Solar Influence on North Atlantic Climate During the Holocene. Science 294 (5549), 2130-2136.

Bond G., Showers W., Cheseby M., Lotti, R., Almasi P., deMenocal P., Priore P., Cullen H., Hajdas I., Bonani G. 1997. A Pervasive Millennial-Scale Cycle in North Atlantic Holocene and Glacial Climates. Science 278, 1257-1266.

Booth R.K., Jackson S.T., Forman S.L., Kutzbach J.E., Bettis E.A., Kreig J., Wright D.K. 2005. A severe centennial-scale drought in mid-continental North America 4,200 years ago and appar- 
ent global linkages. Holocene 15, 321-328.

Boyle J.F., Dearing J.A., Blundell A., Hannam J.A. 2010. Testing competing hypotheses for soil magnetic susceptibility using a new chemical kinetic model. Geology 38, 1059-1062.

Bronger A., Winter R., Heinkele T. 1998. Pleistocene climatic history of East and Central Asia based on paleopedological indicators in loess-paleosequences. Catena 34, 1-17.

Chen F., Holmes J., Wünnemann B., Yu Z. 2009. Holocene climate variability in arid Asia: Nature and mechanism. Editorial. Quaternary International 194, 1-5.

Clark P.U., Marshall S.J., Clarke G.K.C., Hostetler S.W., Licciardi J.M., Teller J.T. 2001. Freshwater forcing of abrupt climate change during the last glaciation. Science 293 (5528), 283287.

Cubasch U., Voss R., Hegerl G.C., Waszkewitz J., Crowley T.J. 1997. Simulation of the influence of solar radiation variations on the global climate with an ocean-atmosphere general circulation model. Climate Dynamics 13, 757-767.

Dansgaard W., Johnsen S.J., Clausen H.B., Dahl-Jensen D., Sundestrup N.S., Hammer C.U., Hvidberg C.S., Steffensen J.P., Sveinbjörnsdottir A.E., Jouzel J., Bond G. 1993. Evidence for general instability of past climate from a $250-\mathrm{kyr}$ ice-core record. Nature 364, 218-220.

Dearing J.A. 1994. Environmental magnetic susceptibility: using the Bartington MS2 System. Chi Publishing, Kenilworth.

Debret M., Bout-Roumazeilles V., Grousset F., Desmet M., McManus J. F., Massei N., Sebag D., Copard Y., Trentesaux A., Petit Y.R. 2007. The origin of the 1500 -year climate cycles in Holocene North-Atlantic records. Clim. Past., 3, 569-575.

deMenocal P., Ortiz J., Guilderson T., Sarnthein M. 2000. Coherent high- and low-latitude climate variability during the Holocene warm period. Science 288, 2198-2202.

Derbyshire E., Kemp R., Meng X.M. 1995. Variations in loess and paleosol properties as indicators of paleoclimatic gradients across the Loess Plateau of north China. Quaternary Science Reviews 14, 681-697.

Derevianko A.P., Krivoshapkin A.I., Anoikin A.A., Wrinn P.J., Islamov U.I. 2004. The lithic industry of Obi-Rakhmat Grotto. In Derevianko A.P. (ed.), Grot Obi Rakhmat, 5-29. Institute of Archaeology and Ethnography, Siberian Branch, Novosibirsk, Russian Academy of Sciences.

Ding Z.L., Ranov V., Yang S.L., Finaev A., Han J.M., Wang G.A. 2002. The loess record in southern Tajikistan and correlation with Chinese loess. Earth and Planetary Science Letters 200, 387-400.

Dodonov A.E. 1991. Loess of Central Asia. Geo. Journal 24, 185-194.

Dodonov A.E. 2002. Quaternary of Middle Asia. Stratigraphy, correlation, paleogeography. Moscow. GEOS 250 (in Russian).

Dodonov A.E., Zhou L. 2008. Loess deposition in Asia: its initiation and development before and during the Quaternary. Episodes 31 (2), 222-225.

Elliot M., Labeyrie L., Duplessy J.C. 2002. Changes in North Atlantic deep-water formation associated with the DansgaardOeschger temperature oscillations (60-10 ka). Quat. Sci. Rev., 21(10), 1153-1165.

Evans M.E., Heller F. 1994. Magnetic enhancement and paleoclimate: study of a loess/paleosol couplet across the loess plateau of China. Geophys. J. Intern., 117, 257-264.

Fleitmann D., Burns S.J., Mudelsee M., Neff U., Kramers J., Mangini A., Matter A. 2003. Holocene forcing of the Indian monsoon recorded in a stalagmite from Southern Oman. Science $300,1737-1739$.

Forster T., Heller F. 1994. Loess deposits from the Tadjik depression (Central Asia): Magnetic properties and paleoclimate. Earth and Planetary Science Letters 128, 501-512.
Ganopolski A., Rahmstorf S. 2001. Rapid changes of glacial climate simulated in a coupled climate model. Nature 409 (6817), 153-158.

Gasse F. 2000. Hydrological changes in the African tropics since the Last Glacial Maximum. Quaternary Science Reviews 19, 189-211.

Geel van. B., Bokovenko N.A., Burova N.D., Chugunov K.V., Dergachev V.A., Dirksen V.G., Kulkova M., Nagler A., Parzinger H., Plicht J. van der., Vasiliev S.S., Zaitseva G.I. 2004. Climate change and the expansion of the Scythian culture after 850 BC: a hypothesis. Journal of Archaeological Science 31, $1735-1742$.

Glantz, M.M., Viola, B., Chikisheva, T. 2004. New hominid remains from Obi-Rakhmat Grotto. In Derevianko A.P. (ed.), Grot Obi-Rakhmat, 77-93. Novosibirsk: Institute of Archaeology and Ethnography, Siberian Branch, Russian Academy of Sciences.

Glantz M.M. 2010. The History of Hominin Occupation of Central Asia in Review. In Norton C.J., Braun D.R. (eds.), Asian Paleoanthropology: From Africa to China and Beyond. Springer.

Grootes P.M., Stuiver M. 1997. Oxygen 18/16 variability in Greenland snow and ice with 103 to 105 -year time resolution. Journal of Geophysical Research 102, 26455-26470.

Guo Z.T., Ruddiman W.F., Hao Q.Z., Wu H.B., Qiao Y.S., Zhu R.X., Peng S.Z., Wei J.J., Yuan B.Y., Liu T.S. 2002. Onset of Asian deserti cation by $22 \mathrm{Myr}$ ago inferred from loess deposits in China. Nature 416, 159-163.

Hartmann K., Wunnemann B. 2008. Hydrological changes and Holocene climate variations in NW China, inferred from lake sediments from Juyenze palaeolake by factor analysis. Quaternary International 194, 28-44.

Heller F., Liu X., Liu T., Xu T. 1991. Magnetic susceptibility of loess in China. Earth and Planetary Science Letters 103, 301310.

Hong Y.T., Hong B., Lin Q.H., Shibata Y., Hirota M., Zhu Y.X., Leng X.T., Wang Y., Wang H., Yi L. 2005. Inverse phase oscillations between the East Asian and Indian Ocean summer monsoons during the last 12,000 yrs and paleo-El Nino. Earth and Planetary Science Letters 231, 337-346.

Huber C., Leuenberger M., Spahni R., Flückiger J., Schwander J., Stocker T. F., Johnsen S., Landais A., Jouzel J. 2006. Isotope calibrated Greenland temperature record over Marine Isotope Stage 3 and its relation to CH4. Earth and Planetary Science Letters. 243(3-4), 504-519.

Islamov U.I., Zubov A.A., Kharitonov V.M. 1988. Paleoliticheskaya stoyanka Sel Ungur v Ferganskoi doline. Voprosy antropologii $80,38-49$.

Issmer K. 2009. Badania multiproxy - nowe trendy w badaniach paleoklimatycznych holocenu, założenia metodologiczne. Geografia UAM 88, 109-125.

Issmer K. 2010. Wpływ cech litologicznych na podatność magnetyczną lessów z rejonu Wzgórz Dalkowskich. Badania fizjograficzne. Seria A. Geografia fizyczna (A61), 170-80., DOI 10.2478/v10116-010-0010-4.

Jary Z. 2007. Zapis zmian klimatu w górnoplejstoceńskich sekwencjach lessowo-glebowych w Polsce i w zachodniej części Ukrainy. Rozprawy Naukowe Instytutu Geografii i Rozwoju Regionalnego Uniwersytetu Wrocławskiego, Wrocław.

Johnsen S.J., Clausen H.B., Dansgaard W., Fuhrer K., Gundestrup N., Hammer C.U., Iversen P., Jouzel J., Stauffer B., Steffensen J. P. 1992. Irregular glacial interstadials recorded in a new Greenland ice core. Nature 359 (6393), 311-313.

Kovaleva N. 2004. Northern Tian Shan paleosoil sedimentary sequences as a record of major climatic events in the last 30,000 years. Revista Mexicana Ciencias Geológicas 21, 71-78.

Kovaleva N. 2005. Paleoclimatic significance of the loess-paleosol 
sequences from Tien Shan, Central Asia. Geophysical Research Abstracts 7, ID: 1607-7962/gra/EGU05-A-01339.

Kukla G., An Z. 1989. Loess stratigraphy in Central China. Paleogeography, Paleoclimatology, Paleoecology 72, 203-225.

Kukla G.T. 1987. Loess stratigraphy in Central China. Quaternary Science Reviews 6, 191-219.

Kukla G., An Z. 1989. Loess stratigraphy in Central China. Paleogeography, Paleoclimatology, Paleoecology 72, 203-225.

Lai Z.P., Wintle A.G., Thomas D.S.G. 2007. Rates of dust deposition between $50 \mathrm{ka}$ and $20 \mathrm{ka}$ revealed by OSL dating at Yuanbao on the Chinese Loess Plateau. Paleogeography, Paleoclimatology, Paleoecology 248, 431-439.

Lamb H.F., Gasse F., Benkaddour A., El Hamouti N., van der Kaars S., Perkins W.T., Pearce N.J., Roberts C.N. 1995. Relation between century scale Holocene arid intervals in tropical and temperate zones. Nature 373, 134-137.

Lamy F., Arz H.W., Bond G.C., Bahr A., Patzold J. 2006. Multicentennial scale hydrological changes in the Black Sea and northern Red Sea during the Holocene and the Arctic/North Atlantic oscillation. Paleoceanography 21, PA1008 DOI:10.1029/2005PA001184.

Li J.F. 1992. On the eve of the Silk Way and climate change. Chinese Historical Geography 125. China Higher Education, Press. Beijing.

Liu T.S., Ding Z.L. 1998. Chinese loess and paleomonsoon. Annual Review of Earth and Planetary Sciences 26, 111-145.

Madella M., Fuller D.Q. 2006. Paleoecology and the Harappan Civilization of South Asia: a reconsideration. Quaternary Science Reviews 25, 1283-1301.

Maher B.A., Thompson R. 1991. Mineral magnetic record of the Chinese loess. Geology 19 (1), 3-6.

Maher B.A., Thompson R. 1995. Paleorainfall Reconstructions from Pedogenic Magnetic Susceptibility Variations in the Chinese Loess and Paleosols. Quaternary Research 44, 383-391.

Mavlyanov G.A., Kasymov S.M., Shermatov M.Sh. 1987. The Uzbekistan loess, genesis and distribution. Geo. Journal 15, 145-150.

Mayewski P.A., Rohling E., Stager E., Karlen J.C., Maasch W., Meeker A., Meyerson L.D., Gasse E.A., van Kreveld F., Holmgren S., Lee-Thorp K., Rosqvist J., Rack G., Staubwasser F., Schneider M., Steig R.R. 2004. Holocene climate variability. Quaternary Research 62, 243-255.

Mestdagh H., Haesaerts P., Dodonov A., Hus J. 1999. Pedosedimentary and climatic reconstruction of the last interglacial and early glacial loess-paleosequence in South Tadzhikistan. Catena $35,197-218$.

Murray A.S., Wintle A.G. 2000, Luminescence dating of quartz using an improved single-aliquot regenerative dose protocol. Radiation Measurements 32, 57-73.

Nawrocki J., Wójcik A., Bogucki A. 1996. The magnetic susceptibility record in the Polish western Ukrainian less-palaeosol sequence conditioned by palaeoclimate. Boreas 25, 161-169.

Neff U., Burns S.J., Mangini A., Mudelsee M., Fleitmann D., Matter A. 2001. Strong coherence between solar variability and the monsoon in Oman between 9 and 6 kyr ago. Nature 411, 290-293.

Overpeck J.T., Cole J.E. 2006. Abrupt change in Earth's climate system. Annu. Rev. Environ. Resour., 31(1), 1-31.

Pavlov A.P. 1888. Genetic types of continental formations in the glacial and post-glacial periods. Izdvestiya Geologicheskogo Komiteta 7 (7) (in Russian).

Pavlov A.P. 1898. The topography of plains and its modification under the action of underground and surface waters. Zemlevedenie 3-4, 105-130 (in Russian).

Petersen S.V., Schrag D. P., Clark P.U. 2013. A new mechanism for Dansgaard-Oeschger cycles. Paleoceanography 28, 24-30.
Piotrowski A.M., Goldstein S.L., Hemming S.R., Fairbanks R.G., Zylberberg D.R. 2008. Oscillating glacial northern and southern deep water formation from combined neodymium and carbon isotopes. Earth and Planetary Science Letters 272(1-2), 394-405.

Pisias N.G., Clark P.U., Brook E.J. 2010. Modes of global climate variability during Marine isotope stage $3(60 \mathrm{ka})$. J. Clim., 23(6), 1581-1588.

Possehl G.L. 1997. The transformation of the Indus civilization. Journal of World Prehistory 11, 425-472.

Pye K. 1987. Aeolian dust and dust deposits. Academic Press. London.

Pye K., Sherwin D. 1999. Loess. In Goudie, A.S., Livingstone, I., Stokes, S. (eds.), Aeolian Environments, Sediments and Landforms. John Wiley \& Sons, UK.

Ranov V., Davis R. 1979. Toward a new understanding of the Soviet Central Asian Paleolithic. Current Anthropology 20, 249270.

Ricketts R.D., Johnson T.C., Brown E.T., Rasmussen K.A., Romanovski V.V. 2001. The Holocene limnology of lake IssykKul, Kyrgyzstan: trace elements and stable isotope composition of ostracodes. Palaeogeography, Palaeoclimatology, Palaeoecology 176, 207-227.

Roberts H.M., Wintle A.G. 2001. Equivalent dose determinations for polimineralic ne-grains using the SAR protocol: Application to a Holocene sequence of the Chinese Loess Plateau. Quaternary Science Reviews 20, 859-863.

Rozwadowski A. 2001. The forgotten art of ancient Uzbekistan. The Times of Central Asia 3 (4/99), 1-5.

Rozwadowski A. 2004. Symbols through Time. Interpreting the Rock Art of Central Asia. Poznań.

Rutter N., Ding Z., Liu T. 1991. Comparison of isotope stages 1-61 with the Baoji-type pedostratigraphic section of north-central China. Canadian Journal of Earth Sciences 28, 985-990.

Shackleton N.J., An Z., Dodonov A.E., Gavin J., Kukla G.J., Ranov V.A., Zhou L.P. 1995. Accumulation rate of loess in Tadjikistan and China. Relationship with global ice volume cycles. Quaternary Proceedings 4, 1-6.

Smalley I. J., Mavlyanova N. G., Rakhmatullaev Kh. L., Shermatov M. Sh., Machalett B., O'Hara Dhand K., Jefferson I. F. 2006. The formation of loess deposits in the Tashkent region and parts of Central Asia; and problems with irrigation, hydrocollapse and soil erosion. Quaternary International 152-153, 59-69.

Smalley I.J., Jefferson I.F., Dijkstra T.A., Derbyshire E. 2001. Some major events in the development of the scientific study of loess. Earth-Science Reviews 54, 5-18.

Staubwasser M., Sirocko F., Grootes P., Segl M. 2003. Climate change at the $4.2 \mathrm{ka}$ BP termination of the Indus valley civilization and Holocene south Asian monsoon variability. Geophysical Research Letters 30: 1425 DOI:10.1029/2002GL016822.

Staubwasser M., Sirocko F., Grootes P.M., Erlenkeuser H. 2002. South Asian monsoon climate change and radiocarbon in the Arabian Sea during early and middle Holocene. Paleoceanography 17: 1063, DOI:10.1029/2000PA000608.

Staubwasser M., Weiss H. 2006. Holocene climate and cultural evolution in late prehistoric-early historic West Asia. Quaternary Research 66 (3), 372-387.

Stevens T., Armitage S.J., Lu H.Y., Thomas D.S.G. 2006. Sedimentation and diagenesis of Chinese loess: Implications for the preservation of continuous, high resolution climate records. Geology 34, 849-852.

Sun D.H., Bloemendal J., Rea, D.K., Vandenberghe J., Jiang F., An Z.S., Su R. 2002. Grain size distribution function of polymodal sediments in hydraulic and aeolian environments and numerical partitioning of the sedimentary components. Sedimentary 
Geology 152, 263-277.

Sun Y., Clemens S.C., An Z., Yu Z. 2006. Astronomical timescale and paleoclimatic implications of tacked 3.6 Myr monsoon records from the Chinese Loess Plateau. Quarternary Science Reviews 25, 33-48.

Tang Y., Jia J., Xie X. 2003. Records of magnetic properties in Quaternary loess and its paleoclimatic signi cance: a brief review. Quaternary International 108, 33-50.

Thompson R., Oldfield F. 1986. Environmental Magnetism. Allen and Unwin, London.

Verosub K. L., Roberts A.P. 1995. Environmental Magnetism: past, present and future. Journal of Geophysical Research 100, 2175-2192.

Vishnyatsky L. 1999. The Paleolithic of Central Asia. Journal of World Prehistory 13, 69-122.

Voelker A.H.L. 2002. Global distribution of centennial-scale records for Marine Isotope Stage (MIS) 3: a database. Quat. Sci. Rev., 21(10), 1185-1212.

Wanner H., Beer J., Bütikofer J., Crowley T.J., Cubasch U., Flückiger J., Goosse, H., Grosjean, M., Joos F., Kaplan J.O., Küttel M., Müller S.A., Prentice I.C., Solomina0 O., Stocker T.F., Tarasov P., Wagner M., Widmann M. 2008. Mid - to Late Holocene climate change: an overview. Quaternary Science Reviews 27, 1791-1828.

Weiss H. 1997. Akkade. In: Meyers, M. (ed.), The Oxford Encyclopedia of Archaeology in the Near East 1, 41-44. New York.

Weiss H. 2000. Beyond the Younger Dryas: collapse as adaptation to abrupt climate change in ancient West Asia and the eastern Mediterranean. In Bawden G., Reycraft R. (eds.), Confronting natural disaster: engaging the past to understand the future,
75-98. University of New Mexico Press. Albuquerque.

Weiss H., Bradley R.S. 2001. Archaeology, what drives societal collapse? Science 291, 609-610.

Weiss H., Courty M.A., Wetterstrom W., Guichard F., Senior L., Meadow R., Curnow A. 1993. The genesis and collapse of 3rd millennium north Mesopotamian civilization. Science 261, 995-1004.

Welc F., Marks L. 2013. Climate change at the end of the Old Kingdom in Egypt around 4200 BP: New geoarchaeological evidence. Quaternary International 324, 124-133.

Wunnemann B., Mischke S., Chen F.H. 2006. A Holocene sedimentary record from Bosten Lake, China. Palaeogeography Palaeoclimatology Palaeoecology 234, 223-238.

Yeliseyev V.I. 1973. On the loess soils of Middle Asia and Kazakhstan. Byulleten Komissii po Izucheniya Chetvertinchnogo Perioda 40, 52-68 (in Russian).

Yang B., Wang J., Brauning A., Dong Z., Esper J. 2008. Late Holocene climatic and environmental changes in arid central Asia. Quaternary International 194, 68-78.

Zhao, Y., Yu, Z.C., Chen F.H. 2008. Spatial and temporal patterns of Holocene vegetation and climate changes in arid and semiarid China. Quaternary International 194, 6-18.

Zhou L.P., Oldfield F., Wintle A.G., Robinson S.G., Wand J.T. 1990. Partly pedogenetic origin of magnetic variations in Chinese loess. Nature 346, 737-739.

Zhou L.P., Shackleton N.J. 2001. Photon stimulated luminescence of quartz from loess and effects of sensitivity change on paleodose determination. Quaternary Science Reviews 20, 853-857. 